\title{
Scientific evidence about Ozone Therapy in Pain Medicine [abstract]
}

\section{Jose Baeza-Noci}

Orhopedic Trauma and Surgery. Hospital Vithas Nisa Virgen del Consuelo. Valencia, Spain

\section{ABSTRACT}

\section{OPEN ACCESS}

\section{Citation}

Baeza-Noci J. Scientific evidence about Ozone Therapy in Pain Medicine [abstract]. Proceedings of The World Conference on Ozone Therapy in Medicine, Dentistry and Veterinary. Ancona (Italy). September 22nd - 23rd - 24th , 2017. J Ozone Ther. 2019;3(4):3-5. doi: 10.7203/ jo3t.3.4.2019.15394

\section{Academic Editor Jose Baeza-Noci, \\ School of Medicine, Valencia University, SPAIN}

\section{Editor}

World Federation of Ozone Therapy, Bolgna, ITALY

\section{Received}

June 17, 2019

\section{Accepted}

December 08, 2019

\section{Published}

December 30, 2019

\section{Intellectual Property}

Jose Baeza-Noci.

This is an open access article distributed under the terms of the Creative Commons Attribution License (CC BY 4.0), which permits unrestricted use, distribution, and reproduction in any medium, provided the original author and source are credited.

\section{Author Information} baeza@comv.es
Purpose. To compare the level of recommendation of ozone therapy in pain medicine with the established techniques in a pain unit.

Design. We used the SIGN (Scottish Intercollegiate Guidelines Network) Guide 136 developed in 2013 to evaluate the recommendation level of the different techniques used in pain units. As some interventional techniques are not included in this study (radiofrequency, peripheral blocks, neurostimulation, morphine pump infuser), other studies were included from IASP (International Association for the Study of Pain) and Spanish Foundation on Rheumatology to complete our evaluation.

Results. A very few techniques in pain units are have a grade $A$ recommendation (very high). Most of them (drugs, physical therapy, psychologically based interventions, radiofrequency and peripheral blocks) have a grade $\mathrm{B}$ (high) or $\mathrm{C}$ (moderate) level of recommendation.

Ozone has a B level of recommendation for osteoarticular pain and for mixed pain (lumbosciatalgia) and a $D$ (low recommendation) level for neuropathic pain and central pain.

Discussion. The integration of ozone therapy inside orthodox medicine is difficult because many colleagues have prejudices against it due to ignorance. We must create evidence, compare to standard procedures and show the results in meetings and publications so all the scientific community gets aware of the real situation.

In this case, pain medicine, ozone has the highest number of publications and the highest level of evidence.

Conclusion. Ozone has enough level of recommendation so as to be included as a standard procedure inside pain units.

Grade $D$ and $C$ indications and others with a physiopathlogical concordance with, should be studied in randomized control trials to expand ozone indications in pain medicine.

Grade B indications should be better studied to reach an A level if ethically possible.

\section{References:}

1. Sackett DL, Rosenberg WM, Gray JA, Haynes RB, Richardson WS. Evidence based medicine: What it is and what it isn't. BMJ. 1996;13:71-72.

2. SIGN. Management of chronic pain. Available from: http:// www.sign.ac.uk/assets/sign136.pdf [Accessed: 7th July 2017].

3. IASP. Evidence-Based Invasive Treatment of Chronic Musculoskeletal 
Pain. Available from: https://www.iasp-pain.org/files/Content/ Content Folders/G I o b a I Ye a r A a inst Pain 2 / MusculoskeletalPainFactSheets/InvasiveTreatment_Final.pdf [Accessed: 7th July 2017].

4. Medel Rebollo, J et al. Técnicas mínimamente invasivas en el tratamiento del dolor crónico. Fund Esp Reum. 2013;14(4):135-141.

5. Ministerio de Sanidad de España. Unidad de Tratamiento del Dolor. Estándares y recomendac[iones de calidad y seguridad. Available from: http://www.msc.es/organizacion/sns/planCalidadSNS/docs/EERR/ Unidad_de_tratamiento_del_dolor.pdf [Accessed: 7th July 2017].

6. Steppan J, Meaders T, Muto M, Murphy KJ. A metaanalysis of the effectiveness and safety of ozone treatments for herniated lumbar discs. J Vasc Interv Radiol. 2010 Apr;21(4):534-548.

7. Magalhaes FN, Dotta L, Sasse A, Teixera MJ, Fonoff ET. Ozone therapy as a treatment for low back pain secondary to herniated disc: a systematic review and meta-analysis of randomized controlled trials. Pain Physician. 2012 Mar-Apr; 15(2):E115-129.

8. Dall'Olio M, Princiotta C, Cirillo L, Budai C, de Santis F, Bartolini S, Serchi E, Leonardi M. Oxygen-ozone therapy for herniated lumbar disc in patients with subacute partial motor weakness due to nerve root compression. Interv Neuroradiol. 2014 Oct 31;20(5):547-554. doi: 10.15274/INR-2014-10078.

9. Juncopilla N, Franzini M. The therapy involving the infiltration of oxygenozone intradisc and interfacet. 1er Congreso de la Sociedad Española de abordajes percutaneos vertebrales. Barcelona; 1995.

10. Muto M, Andreula C, Leonardi M. Treatment of herniated lumbar disc by intradiscal and intraforaminal oxygen-ozone (O2-O3) injection. J Neuroradiol. June 2004;31(3):183-189.

11. Scuccimarra A. [The "Laminoforaminal Technique" in Oxygen-Ozone Therapy for Lumbar Disc Herniation]. Riv Ital Ossigeno-Ozonoterapia. 2003;2(2):193-196.

12. Verga C. Nuovo approccio terapeutico alle ernie e protusioni discali Iombari. Riv. Neuroradiol. $1989 ; 2: 148$. doi : $10.1177 / 19714009890020 S 139$.

13. Bonetti M. [CT-Guided Oxygen-Ozone Infiltration into Isthmic Lysis Points in the Management of 1st Degree Spondylolisthesis and Spondylolysis]. Riv Ital Ossigeno-Ozonoterapia. 2003;2(1):31-38.

14. Borrelli E. Mechanism of action of oxygen ozone therapy in the treatment of disc herniation and low back pain. Acta Neurochir Suppl. 2011;108:123-125. doi: 10.1007/978-3-211-99370-5_19.

15. Mattozi I, Laurini G, Muzzi G, Franzini M, Bigiotti A. Intrasacral epidural injection with oxygen-ozone for the treatment of low back pain. Comparison and evaluation with other techniques and rehabilitation and return to work. Eur J Clin Invest. 2003;33 (suppl. 1):45.

16. Moretti B, Lanzisera R, Pesce V, Moretti L, Patella S, Patella V. Simone C. O2-O3 vs anti-inflammatory drugs in the treatment of neck pain. Riv Ital Ossigeno-Ozonoterapia 2004;3:131-137.

17. Albertini F. Ozone administration in the treatment of herniated cervical disc. Case report. Rivi Ital Ossigeno-Ozonoterapia 2002;1:203-206. 
18. Villa G. C6-C7 herniated disc treatment with paravertebral oxygen-ozone infiltration. Rivi Ital Ossigeno-Ozonoterapia 2002;1:199-201.

19. Xiao YY, Tian JL, Li JK, Zhang JS. CT.Guided ozone injection for the treatment of cervical disc herniation. Riv Ital Ossigeno-Ozonoterapia 2006;5:109-115.

20. Alexandre A, Corò L, Azuelos A, et al. Intradiscal injection of oxygenozone gas mixture for the treatment of cervical disc herniations. Acta Neurochir Suppl. 2005;92:79-82

21. Moretti B., Lanzisera R., Morese A. [O2-O3 vs chondroprotectors in the treatment of osteoarthritis of the knee]. Riv Ital Ossigeno-Ozonoterapia. 2004;3:65-72.

22. Moretti, M. Effectiveness of Treatment with Oxygen-Ozone and Hyaluronic Acid in Osteoarthritis of the Knee. Int $\mathrm{J}$ Ozone Ther. 2010;9:25-29.

23. Jesus, C, Trevisani, V, Santos F. Comparison Between Intra Articular Ozone and Placebo in the Treatment of Knee Osteoarthritis: A Multicentric, Comparative, Randomized and Double-Blinded Clinical Trial. Arthritis Rheumatol. 2015;67(suppl 10)

24. Hidalgo-Tallón J, Menéndez-Cepero S, Vilchez JS, Rodríguez-López CM, Calandre EP. Ozone therapy as add-on treatment in fibromyalgia management by rectal insufflation: an open-label pilot study. J Altern Complement Med. 2013;19(3):238-242.

25. Konrad $\mathrm{H}$. Ozone therapy for postherpetic neuralgia. A retrospective study of 55 cases. Proceedings of the 15th Ozone World Congress, London, UK, 11th-15th September 2001. Medical Therapy Conference (IOA 2001, Ed.), Speedprint MacMedia Ltd, Ealing, London UK, p. 85-88.

26. Moretti B, Lanzisera R, Sisti GL, Moretti L, Patella S, Patella V, Simone C. O2-O3 therapy in tendinopathies and entrapment syndromes. Riv Ital Ossigeno-Ozonoterapia 2005;4:20-29.

27. Ikonomidis ST, Iliakis EM, Charalambus Dvakirtzian L. Nonoperative treatment of shoulder impingement syndrome with topical injections of medical oxygen-ozone mixture. A double blind clinical trial. Riv Ital Ossigeno-Ozonoterapia 2002;1:41-44.

28. Trenti GF, Gheza G. Efficacy of oxygen-ozone pain therapy associated with shock waves to treat calcifying tendinitis of the shoulder. Preliminary findings. Riv Ital Ossigeno-Ozonoterapia 2002;1:45-50.

29. Brina L, Villani PC. Treatment of rotator cuff lesions with echo-guided infiltration of an oxygen-ozone mixture. Riv Ital Ossigeno-Ozonoterapia 2004;3:139-147.

30. Ikonomidis ST, Iliakis EM, Eleftheriadou A, Bratanis D, Thomaidis R. Conservative treatment of acute or chronic tendinitis with oxygen-ozone mixture. A double blind clinical trial. Riv Ital Ossigeno-Ozonoterapia. 2003;2:67-71.

31. Gaffuri M, Garaffo R, Gheza G. Oxygen-ozone therapy for lateral humeral epicondylitis: preliminary findings. Riv Ital OssigenoOzonoterapia. 2003;2:169-172.

32. Bonetti M, Fontana A, Cotticelli B, Fiorentini R. Intra-articular disease of the temporomandibular joint: ozone Therapy. Preliminary findings. Riv Ital Ossigeno-Ozonoterapia. 2004;3:113-119. 